\title{
Iatrogenic alkalosis in goats with the use of intravenous electrolyte solution containing $84 \mathrm{mEq} / \mathrm{L}$ of lactate
}

\author{
Priscilla Fajardo Valente Pereira ${ }^{* *}$ (D) Fernanda Tamara Neme Mobaid Agudo Romão ${ }^{2}$ (D) \\ Juliana Massitel Curti ${ }^{3}$ (D) Stefany Lia de Oliveira Camilo1 ${ }^{1}$ \\ Karina Keller Marques da Costa Flaiban $^{3}$ (D) Júlio Augusto Naylor Lisbôa ${ }^{1}$ (D)
}

1Departamento de Clínicas Veterinárias, Universidade Estadual de Londrina (UEL), 86057-970, Londrina, PR, Brasil. E-mail: pri_fajardo@yahoo.com.br.
${ }^{*}$ Corresponding author.
${ }^{2}$ Departamento de Medicina Veterinária, Faculdade de Ensino Superior e Formação Integral de Garça (FAEF), Garça, SP, Brasil.
${ }^{3}$ Departamento de Medicina Veterinária Preventiva, Universidade Estadual de Londrina (UEL), Londrina, PR, Brasil.

ABSTRACT: This study investigated the alkalinizing potential of an intravenous polyionic solution containing $84 \mathrm{mEq} / \mathrm{L}$ of lactate on hydroelectrolyte and acid-base balances in healthy goats.Four solutions, containing 28 and $84 \mathrm{mEq} / \mathrm{L}$ of lactate (L28 and L84) or bicarbonate (B28 and B84), were formulated. Six healthy Saanen goats were used. All four solutions were infused intravenously in each animal, one at a time, with an interval of 4-5 days between the infusions, at a speed of $33.3 \mathrm{~mL} / \mathrm{kg} / \mathrm{h}$ and totaling a volume equivalent to $10 \%$ of their body weight, in 3 h of continuous administration. Samples of venous blood and urine were collected at 0h (start of the infusion), 1.5h (middle of the infusion), $3 \mathrm{~h}$ (end of the infusion), and $4.5 \mathrm{~h}, 6 \mathrm{~h}$, and $24 \mathrm{~h}$ from the start of the infusion. The laboratory tests includeddetermination of blood $\mathrm{pH}$, $\mathrm{pCO}_{2}, \mathrm{HCO}_{3}^{-}$, base excess (BE), $\mathrm{Na}^{+}, \mathrm{K}^{+}, \mathrm{Cl}$, total plasmatic protein, L-lactate, and creatinine. In urine samples, $\mathrm{pH}, \mathrm{Na}+\mathrm{K}^{+}, \mathrm{Cl}^{-}, \mathrm{L}$-lactate, and creatinine were measured. The L28 solution, equivalent to lactated Ringer's solution, caused a slight increase in the alkaline reserve and did not change the electrolyte balance. The L84 solution resulted in a greater increase in the alkaline reserve, equivalent to the B84 solution, with return to baseline values within $24 \mathrm{~h}$ from the start of the infusion. The L84 solution proved to be safe and produced iatrogenic alkalization when infused into healthy goats, without causing side effects.

Key words: caprine, acid-base balance, fluid therapy, metabolic acidosis.

Alcalose iatrogênica em cabras após infusão intravenosa de solução eletrolítica contendo $84 \mathrm{mEq} / \mathrm{L}$ de lactato

RESUMO: $O$ objetivo deste trabalho foi investigar o potencial alcalinizante de uma solução poli-iônica intravenosa contendo $84 m E q / L$ de lactato no equilíbrio hidroeletrolítico e ácido base de cabras saudáveis. Quatro soluções contendo 28 e $84 \mathrm{mEq} / \mathrm{L}$ de lactato (L28 e L84) ou bicarbonato (B28 e B84) foram formuladas. Seis cabras, adultas, da raça Saanen, saudáveis receberam as quatro soluções por via intravenosa, uma de cada vez, com intervalo de quatro a cinco dias entre as infusões, a velocidade de 33,3 ml/kg/h, totalizando um volume equivalente a $10 \%$ do seu peso corporal, em três horas de administração contínua. Foram coletadas amostras de sangue venoso e urina antes do início da infusão (0h), na metade (1,5h), no fim (3h) e às 4,5h, 6h e 24 h após o início da infusão. Os exames laboratoriais consistiram na determinação do $\mathrm{pH}$ sanguíneo, $\mathrm{pCO}_{2}, \mathrm{HCO}_{3}, \mathrm{BE}, \mathrm{Na}^{+}, \mathrm{K}^{+}, \mathrm{Cl}$, proteína plasmática total, lactato L e creatinina. Nas amostras de urina foram medidos o $\mathrm{pH}, \mathrm{Na}^{+}, \mathrm{K}^{+}, \mathrm{Cl}$, lactato L e creatinina. A solução L28, equivalente à solução de Ringer com lactato, causou um aumento leve na reserva alcalina e não alterou o equilíbrio eletrolítico. A solução L84 resultou em maior aumento da reserva alcalina, equivalente à solução B84, com retorno dos parâmetros avaliados aos valores basais em até 24 horas após o início da infusão. A solução L84 provou-se segura e produziu alcalose iatrogência em cabras sadias, sem causar qualquer efeito colateral.

Palavras-chave: caprinos, equilíbrio ácido base, fluidoterapia, acidose metabólica.

\section{INTRODUCTION}

Metabolic acidosis is an acid-base imbalance that occurs in several diseases of ruminants, including acute ruminal lactic acidosis (ARLA) (SNYDER \& CREDILLE, 2017), diarrhea, acetonemia, renal failure, hypovolemia, endotoxemia, and septicemic shock (CONSTABLE et al., 2016). Correction of metabolic acidosis is achieved by the administration of solutions containing alkalizing substances such as bicarbonate, which is the preferred buffer since it has an immediate effect (CONSTABLE, 2003; SNYDER \& CREDILLE, 2017). However, rapid administration or administration of large amount can lead to adverse effects, such as iatrogenic alkalosis, hypernatremia, hypokalemia, and decreased ionized calcium (MUIR, 2017). Blood gas analysis is fundamental for the correct calculation of the required 
amount of bicarbonate to be administered; however, this feature is not available for many professionals, especially those who work in the field.

Alternatively, metabolizable bases can also be used as they exert an alkalizing effect due to the consumption of $\mathrm{H}^{+}$ions during their metabolism (CONSTABLE, 2003). Studies have already demonstrated the alkalizing potential of propionate, acetate, and lactate in cattle (NAYLOR \& FORSYTH, 1986; LEAL et al., 2007). In Brazil, only lactate is reported in commercial electrolytic solutions such as lactated Ringer's solution (LRS). Due to a low lactate concentration $(28 \mathrm{mEq} / \mathrm{L})$, the LRS alkalizing potential is reduced or absent in healthy animals (COSENZA et al., 2013; JUNQUEIRA et al., 2015), and this solution is not effective in correcting metabolic acidosis in diarrheic calves (NAKAGAWA et al., 2009) and sheep with ARLA (COSENZA et al., 2015).

In search of a safer alternative for the treatment of metabolic acidosis, an electrolyte solution containing $84 \mathrm{mEq} / \mathrm{L}$ of lactate was developed, and its alkalizing effect was verified in healthy sheep (FLAIBAN, 2010), calves (JUNQUEIRA et al., 2015), and horses (PINTO et al., 2018). This solution has been shown to be effective in correcting metabolic acidosis in sheep with ARLA (FLAIBAN, 2010), calves with diarrhea (JUNQUEIRA, 2012), and horses with hyperchloremic acidosis (ROMÃO et al., 2017). Despite the promising results, the effects of this solution have not yet been tested in goats. This study investigated the alkalizing potential of an electrolytic solution containing $84 \mathrm{mEq} / \mathrm{L}$ of lactate in healthy goats.

\section{MATERIALS AND METHODS}

\section{Solutions}

The crystalloid solutions presented in table 1 were used based on the composition of the commercial LRS (L28) and its osmolarity and sodium content. The lactate concentration was measured in triplicate (L84), and the chloride concentration was reduced. The bicarbonate solutions (B28 and B84) were equimolar to the lactate solutions and were used as the standard of comparison.

The solutions were prepared with commercial sterilized water in $1000 \mathrm{~mL}$ bottles (Water for injection: Halexistar Pharmaceutical Industry, Brazil). The components used in the preparation were sodium chloride $(\mathrm{NaCl})$, potassium chloride ( $\mathrm{KCl})$, calcium chloride $\left(\mathrm{CaCl}_{2}\right)$, sodium bicarbonate $\left(\mathrm{NaHCO}_{3}\right)$, and sodium lactate, which were all pure for analysis (Synth; Labsynth, Brazil). L-lactate concentrations were measured and corresponded to $98 \%$ of the total lactate present. The solutions were prepared shortly before administration by adding the components in appropriate amounts or volume for each type of composition and finally homogenizing them. To avoid any contamination, aseptic care was rigorous and constant throughout solution preparation.

\section{Experimental procedures}

Six healthy, non-pregnant and non-lactating female Saanen young goats $(13,95 \pm 2,42$ months of age) were enrolled in the study. The goats were housed in collective stalls and fed with water and coast-cross grass hay (Cynodondactylon) ad libitum, commercial ration (Cocari Goats adult; Cocari, Brazil) (300 g per animal, divided into two portions per day), and mineral salt (Sal Rural Maringá; SRM, Brazil).

The goats weighed $32.5 \pm 3.5 \mathrm{~kg}$, and a cross-over design was implemented, in which all six goats receiving the four solutions studied one at a time, with an interval of 4-5 days between infusions. Solutions assignments were randomly established. The solutions were infused intravenously, and the left jugular vein was kept catheterized (BD Angiocath ${ }^{\circledR}$

Table 1 - Ionic composition $(\mathrm{mEq} / \mathrm{L})$ and calculated osmolarity of intravenous solutions foradministration in young Saanen goats.

\begin{tabular}{lcccc}
\hline Component & L28 & L84 & B28 & B84 \\
\hline Sodium & 130 & 130 & 130 & 130 \\
Chloride & 109 & 53 & 53 & 4 \\
Potassium & 4 & 4 & 4 & - \\
Calcium & 3 & 3 & - & - \\
L Lactate & 28 & 84 & 28 & 84 \\
Bicarbonate & - & - & 28 & 84 \\
Effective SID & 28 & 84 & 272 & 272 \\
Osmolarity $(\mathrm{mOsm} / \mathrm{L})$ & 275 & 275 & & 27 \\
\hline
\end{tabular}

Ciência Rural, v.51, n.8, 2021. 
18G; Becton Dickinson Ltd., Brazil) for this purpose. The administered volume corresponded to $10 \%$ of body weight and the infusion rate was $33.3 \mathrm{~mL} / \mathrm{kg} / \mathrm{h}$, totaling $3 \mathrm{~h}$ of continuous administration.

Venous blood and urine samples were collected immediately before starting the infusion and after initiation at $1.5 \mathrm{~h}$ (half volume), $3 \mathrm{~h}$ (end of infusion), $4.5 \mathrm{~h}$, and $6 \mathrm{~h}$. An extra sample of blood was collected at $24 \mathrm{~h}$ from the beginning of the infusion. Blood samples were collected by puncturing the right jugular vein. Vacuum tubes (Laborvacum; Labor Import, Brazil) containing sodium fluoride were used, and the fluoridated plasma was obtained by centrifugation (10,000 rpm for 5 minutes) performed within a maximum of 10 minutes. The plasma was preserved by freezing $\left(-20^{\circ} \mathrm{C}\right)$ until analysis. For hemogasometry, $3 \mathrm{~mL}$ plastic syringes containing approximately $0.08 \mathrm{~mL}$ (400 IU) of sodium heparin (Hemofol; Cristália, Brazil) were used, and the samples were processed immediately. Urine samples were either obtained by spontaneous urination or induction by brief manual obstruction of the nostrils and mouth.

Physical examinations (PUGH et al., 2020) were performed every 90 minutes, until 6 hours after starting the infusion and 24 hours later. The animals were monitored for the occurrence of behavioral changes or any other manifestation during the experimental period.

\section{Laboratory procedures}

The blood $\mathrm{pH}$, partial pressure of carbon dioxide $\left(\mathrm{pCO}_{2}\right)$, bicarbonate $\left(\mathrm{HCO}_{3}^{-}\right)$, base excess (BE), sodium $\left(\mathrm{Na}^{+}\right)$, chloride $\left(\mathrm{Cl}^{-}\right)$, and potassium $\left(\mathrm{K}^{+}\right)$were measured using a gas analyzer (Omni C; Roche, Switzerland). Total plasma protein (TPP) concentrations were measured by fresh plasma refractometry. In the frozen plasma, creatinine concentrations were measured by the enzymatic method (Dimension; Siemens, Germany) and L-lactate by the colorimetric method (Dimension; Siemens). In the fresh urine samples, $\mathrm{pH}$ was determined using an electronic potentiometer (PG1800; Gehaka, Brazil) and density by refractometry. In the frozen samples, the creatinine concentrations were determined by the enzymatic method (Dimension; Siemens), L-lactate by colorimetry (Dimension; Siemens), and $\mathrm{Na}^{+}$, $\mathrm{K}^{+}$, and $\mathrm{Cl}^{-}$by the selective ion electrode method (Dimension; Siemens).

The following variables were calculated using the corresponding formulas:

- Strong Ion Difference ( SID $_{3}$ ) (CONSTABLE, 1997): $\mathrm{SID}_{3}=\left(\mathrm{Na}^{+}+\mathrm{K}^{+}\right)-\left(\mathrm{Cl}^{-}\right)$
- Anion Gap (AG) (CONSTABLE, 1999): $\mathrm{AG}=\left(\mathrm{Na}^{+}\right.$

$\left.+\mathrm{K}^{+}\right)-\left(\mathrm{Cl}^{-}+\mathrm{HCO}_{3}^{-}\right)$

- Total concentration of non-volatile weak acids $\left(\mathrm{A}_{\text {tot }}\right)$ (CONSTABLE, 2002):

$\mathrm{A}_{\text {tot }}=\mathrm{TPP}(\mathrm{g} / \mathrm{dL}) \times 3.6$

- Percent change in plasma volume (\%PV) (CARLSON \& BRUSS, 2008):

$\% \mathrm{PV}=\left[\left(\mathrm{TPP}_{1} / \mathrm{TPP}_{2}\right)-1\right] \times 100$

- Urinary fractional excretions of electrolytes and L-lactate (GARRY et al., 1990):

$\mathrm{FE}_{a}=$ (urinary concentration of $a \times$ plasma creatinine / plasma concentration of $a \times$ urine creatinine) $\times 100$, where $a$ is the substance excreted.

\section{Statistical methods}

A bifactorial variance analysis was conducted to test the effects of time (during and after the infusion of solutions) and the type of solution administered, and to verify the existence of interaction between the two factors (time and type of solution). When the F statistic was significant, Tukey's test was used. A probability of error of $5 \%$ was allowed. SigmaStat for Windows 3.1 program was used for statistical analysis.

\section{RESULTS AND DISCUSSION}

The L28 solution, equivalent to LRS, did not affect the $\mathrm{pH}, \mathrm{pCO}_{2}, \mathrm{~K}^{+}, \mathrm{Cl}^{-}$, and $\mathrm{SID}_{3}$ values $(P$ $>0.05)$ but caused slight elevations of $\mathrm{HCO}_{3}{ }^{-}(P<$ $0.001)$, BE $(P<0.001)$, and $\mathrm{Na}^{+}(P<0.001)$ at the end of the infusion (Figures 1 and 2), which returned to the original values at $4.5 \mathrm{~h}$. The $\mathrm{L} 28$ solution did not interfere with the electrolyte and acid-base balance of healthy goats when administered at a volume corresponding to $10 \%$ of body weight. Similar results were observed in healthy sheep, calves, and horses (COSENZA et al., 2013, JUNQUEIRA et al., 2015). These results contradicted the concept that LRS has an alkalizing capacity (CONSTABLE, 2003; JONES $\&$ NAVARRE, 2014) and that it could be used in the treatment of metabolic acidosis in calves (SMITH \& BERCHTOLD, 2014). LRS was not able to correct the metabolic acidosis of calves with diarrhea (NAKAGAWA et al., 2009) and sheep with ALRA (COSENZA et al., 2015). As LRS has a plasma-like electrolyte composition, it is expected that it will not cause electrolyte and iatrogenic acid-base changes (COSENZA et al., 2013; JUNQUEIRA et al., 2015), which was also observed in this study. The alkalizing capacity of LRS is reduced due to the low effective $\mathrm{SID}_{3}$, which has the same concentration as that of lactate $(28 \mathrm{mEq} / \mathrm{L})$ and does not remain in the plasma 


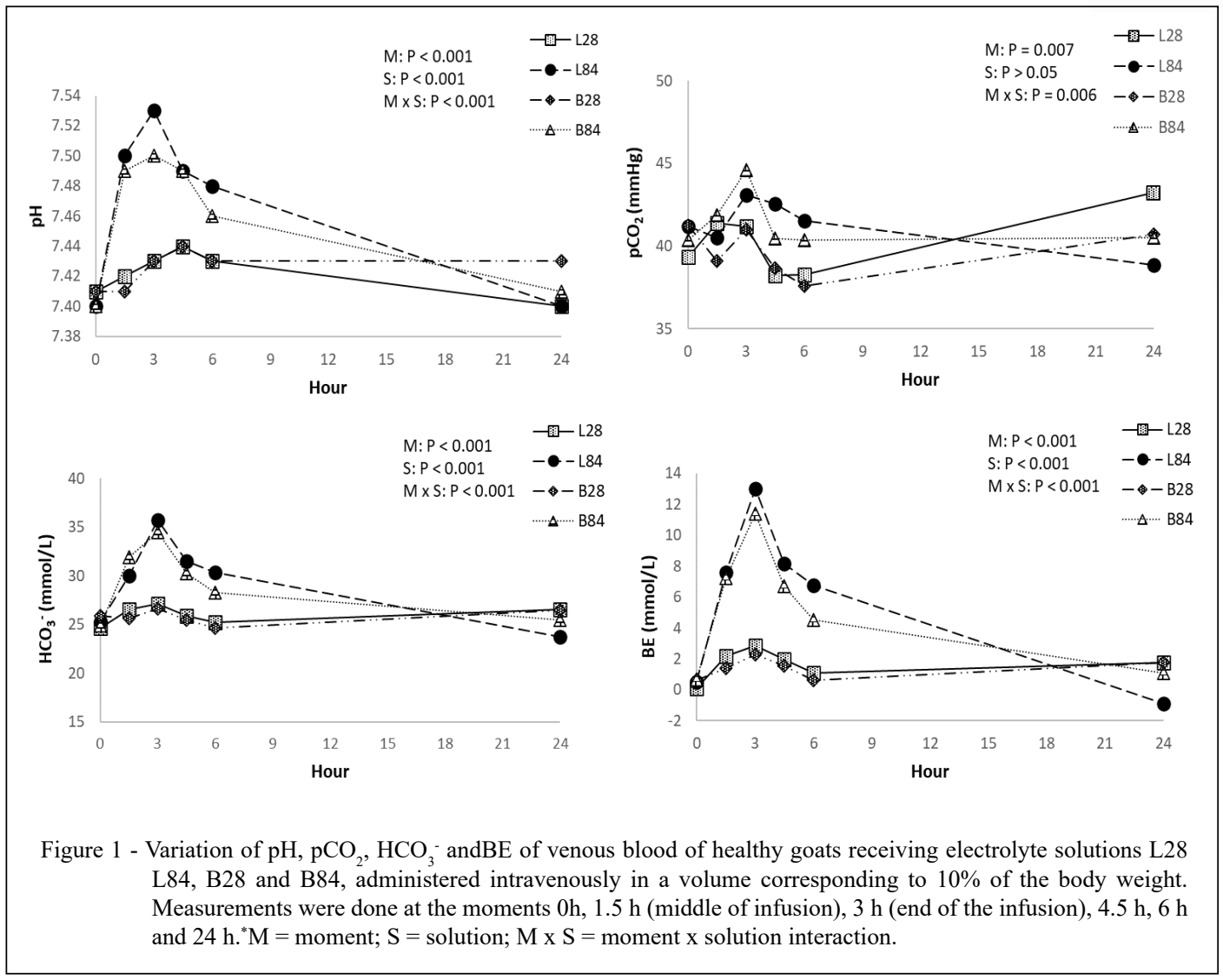

as a strong anion after its metabolism (CONSTABLE, 2014; MUIR, 2017).

The L84 solution, conversely, produced intense elevations of $\mathrm{pH}, \mathrm{HCO}_{3}{ }^{-}$and $\mathrm{BE}(P<0.001)$, starting from the middle of the infusion to reaching its peak toward the end.The $\mathrm{pCO}_{2}$ remained unchanged (Figure 1). With the L84 infusion, $\mathrm{Na}^{+}$concentration increased $(P<0.001)$, whilethat of $\mathrm{K}^{+}(P<0.001)$ and $\mathrm{Cl}^{-}(P=0.02)$ decreased, causing elevation of $\mathrm{SID}_{3}$ $(P=0.003)$ and hypokalemia, which extended from the middle of the infusion to $1.5 \mathrm{~h}$ after its end $(4.5$ h) (Figure 2). These variations were transient, with return to the original values within $6 \mathrm{~h}$ for $\mathrm{Na}^{+}, \mathrm{Cl}^{-}$, and $\mathrm{SID}_{3}$ or the next day ( $24 \mathrm{~h}$ ) for the other variables.

Acid-base and electrolyte changes caused by solutions L28 and L84 were equivalent $(P>0.05)$ to those produced by solutions B28 and B84, respectively. The only exception was in chloremia and $\mathrm{SID}_{3}$, in which the variation obtained from L84 infusion was different from that obtained from B84 infusion. Naturally, the $\mathrm{Cl}^{-}$ concentrations were lower and the $\mathrm{SID}_{3}$ concentrations were higher after the end of the L84 infusion since it contained less $\mathrm{Cl}^{-}$than that of the $\mathrm{B} 84$ solution.
At the end of L84 infusion, elevations of $\mathrm{HCO}_{3}^{-}$and $\mathrm{BE}$ values were accentuated, and the blood $\mathrm{pH}$ reached the upper physiological limit, admitted as 7.54 (CARLSON \& BRUSS, 2008). The compensatory pulmonary response to hypercapnia has not been well characterized in goats. The type and magnitude of the iatrogenic acid-base imbalance were similar to those observed previously in healthy sheep (FLAIBAN, 2010) and calves (JUNQUEIRA et al., 2015). An absence of compensatory hypercapnia was observed in sheep, contrary to that observed in calves. As already FLAIBAN (2010) speculated, it might be possible that, in goats, renal excretion mechanisms promote the rapid correction of alkalosis and make respiratory compensation minimally necessary. In fact, iatrogenic alkalosis was completely corrected on the day after the infusion $(24 \mathrm{~h})$, but at $3 \mathrm{~h}$ after the end of infusion $(6 \mathrm{~h})$, it was already attenuated.

The increase in $\mathrm{Na}^{+}$concentration and decrease in $\mathrm{Cl}^{-}$concentration observed at the end of L84 infusion occurred because of its composition, whose $\mathrm{Cl}^{-}$concentration was much lower than that of plasma. Conversely, hypopotassemia, observed 


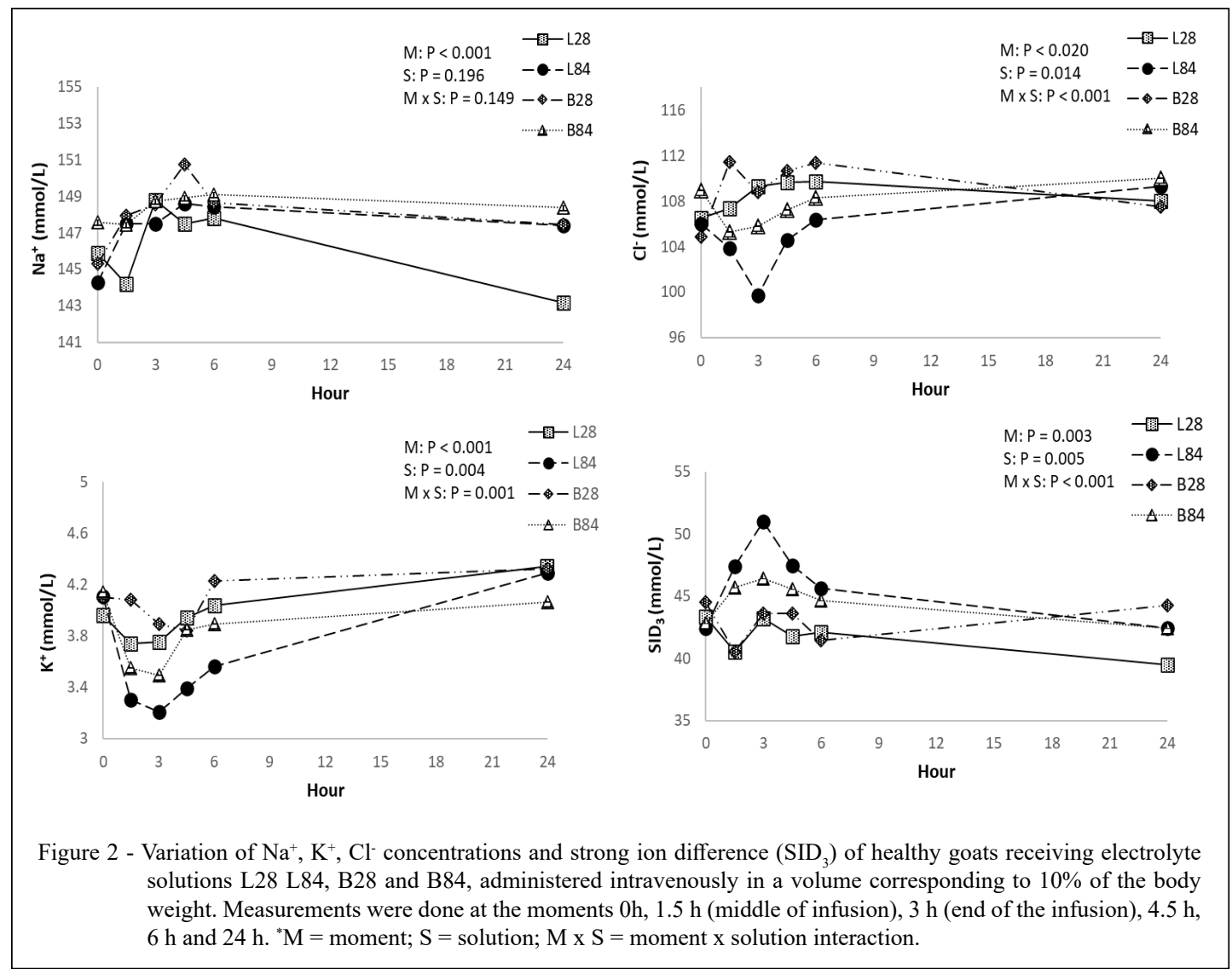

from the middle of the infusion up to $4.5 \mathrm{~h}$, can be considered secondary to plasma volume expansion and iatrogenic metabolic alkalosis, in which $\mathrm{K}^{+}$ enters the cell due to the $\mathrm{Na}^{+} \mathrm{K}^{+}$ATPase activation, with a concomitant exit of $\mathrm{H}^{+}$to the extracellular space (ARONSON \& GIEBISCH, 2011; TREFZ et al. 2015). FLAIBAN (2010) and JUNQUEIRA et al. (2015) also reported that an increase in $\mathrm{Na}^{+}$ concentration, decrease in $\mathrm{Cl}^{-}$concentration, and hypopotassemia occurred after the administration of L84 solution in healthy sheep and calves.

The plasma L-lactate concentration decreased with the infusion of solutions L28, B28, and B84 $(P<0.001)$. The decrease in the plasma L-lactate concentration in animals of the L28 group occurred due to rapid lactate metabolism and mainly due to the hemodilution effect observed after infusion. Conversely, administration of L84 solution resulted in an elevation of L-lactate concentration during the infusion $(P<0.001)$, which reverted to baseline value $1 \mathrm{~h}$ and 30 minutes after its end (4.5 h) (Figure 3). In the middle of the B28 and B84 infusions, L-lactate concentrations were found to be lower than those of the L28 and L84 solutions $(P<0.001)$. L-lactate FE was slightly elevated $(P<0.001)$ after the end of the infusion (4.5 and $6 \mathrm{~h})$, regardless of the type of solution administered $(P=0.525)$. The slight increase in the L-lactate FE after L28 and L84 solutions infusions can be explained by the renal excretion of part of the L-lactate, which was not metabolized. However, the reason for the increase in L-lactate FE after the infusion of solutions containing sodium bicarbonate (B28 and B84) is not known. This result is different from that observed in healthy sheep and calves, which showed no difference in L-lactate FE before, during, or after the solution infusions (FLAIBAN, 2010; JUNQUEIRA et al., 2015). Healthy horses, when receiving L84 solution at a speed of $16.66 \mathrm{~mL} /$ $\mathrm{kg} / \mathrm{h}$, showed an increase in L-lactate FE at the end of the infusion, with a return to baseline values $6 \mathrm{~h}$ after the end of the infusion (PINTO et al., 2018).

Infusion of solutions at a volumecorresponding to $10 \%$ of body weight resulted in a reduction in TPP values $(P<0.001), \mathrm{A}_{\text {tot }}(P<0.001)$, and AG $(P=$ $0.008)$, and an increase in $\% \mathrm{PV}(P<0.001)$ (Figure 3$)$. These effects occurred without distinction between the 


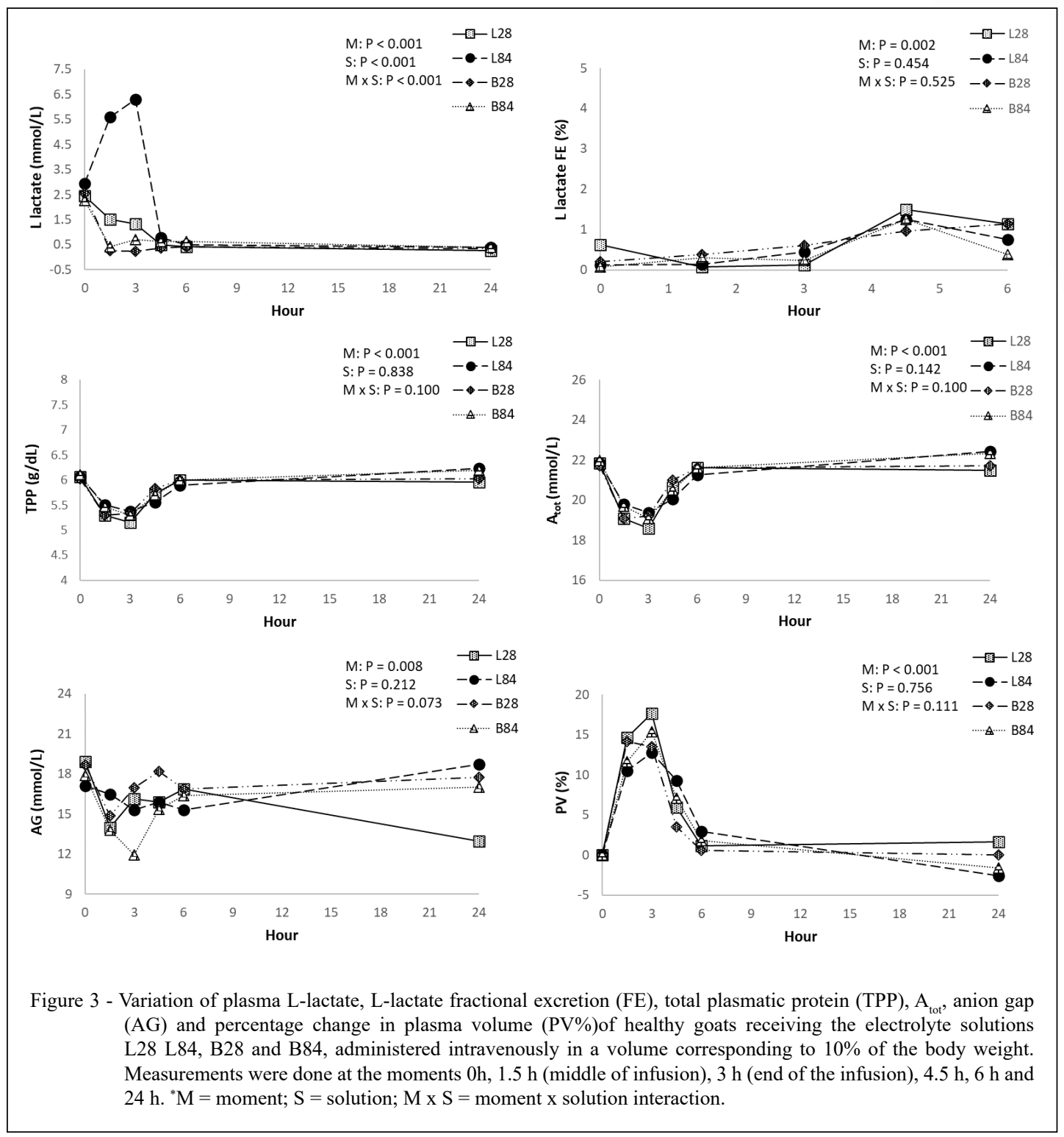

solutions $(P>0.05)$ and were transient, observed from the middle of the infusion, and returned to the original values $3 \mathrm{~h}$ after the end $(6 \mathrm{~h})$. The observed reductions in TPP, $A_{\text {tot }}$, and AG occurred due to hemodilution caused by the administration of the solutions in a volume corresponding to $10 \%$ of body weight in healthy, nondehydrated animals. The elevation in \% PV confirmed this. According to the strong ion model, $\mathrm{A}_{\text {tot }}$ represents the negative charge of plasma proteins and has an influence on the acid-base balance (CONSTABLE, 2014; MUIR, 2017). Hypoproteinemia, reflected in the reduction of this variable, is one of the causes of metabolic alkalosis
(CONSTABLE, 2014). However, the decrease in $A_{\text {tot }}$ should not be considered as an additional cause of the alkalizing effect observed in goats, since it also occurred after the administration of all the solutions used in the present study.

The frequency of urination increased during the infusion. Urine presented a lower density $(P<0.001)$ from the middle of the infusion, and the original values were recovered $3 \mathrm{~h}$ after the end of infusion $(6 \mathrm{~h})$. The $\mathrm{pH}$ of the urine did not change over time $(P=0.059)$; however, at $4.5 \mathrm{~h}$, the L84 solution caused higher values than those of L28 $(P=0.014)$ 


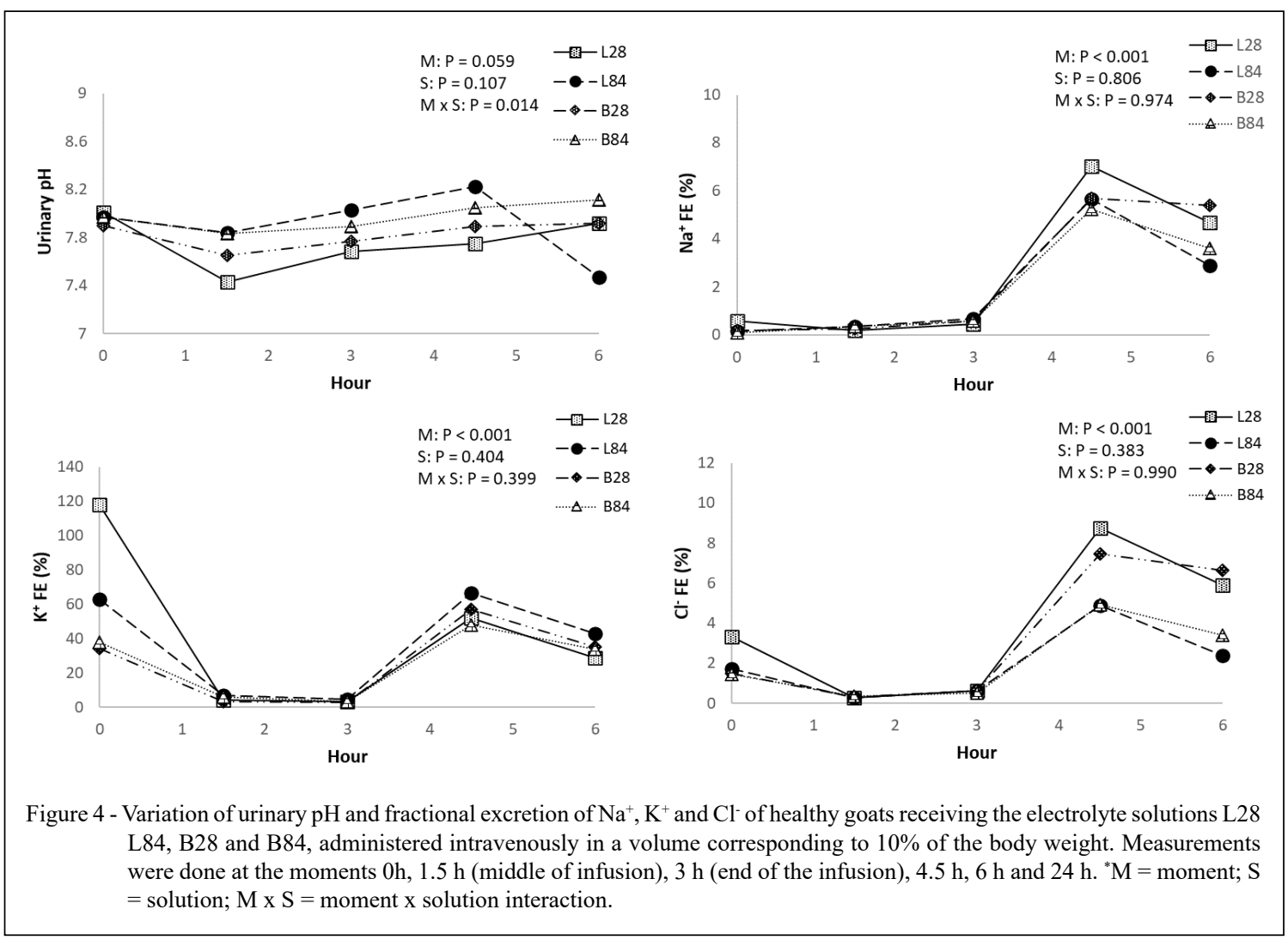

(Figure 4). An increase in urinary $\mathrm{pH}$ would be expected due to the elimination of bicarbonate owing to the renal mechanism for correcting the acid-base imbalance caused by infusing alkaline solutions. Urine from adult ruminants is naturally alkaline, and additional alkalization is not always apparent after the administration of alkalizing solutions (CARLSON \& BRUSS, 2008). Similar results have been reported for healthy sheep (FLAIBAN, 2010). $\mathrm{Na}^{+}$and $\mathrm{Cl}^{-} \mathrm{FE}$ increased $(P<0.001)$ after the end of L84 infusion, and $\mathrm{K}^{+} \mathrm{FE}$ decreased during the infusion $(P<0.001)$ of all solutions studied (Figure 4). Except for $\mathrm{pH}$, the variables studied in urine were not affected by the type of solution administered $(P>0.05)$. All iatrogenic electrolyte changes were transient and corrected by the kidneys through selective excretion of ions. An increase in $\mathrm{FE}$ of $\mathrm{Na}^{+}$and $\mathrm{Cl}^{-}$is necessary to maintain homeostasis, minimizing the imbalance caused by the administration of excess electrolytes (LUNN \& MCGUIRK, 1990). The decrease in $\mathrm{K}^{+}$ FE during infusion, with return to original values at $4.5 \mathrm{~h}$, occurred in response to hemodilution, hyperhydration, and the need to excrete excess liquid in the studied animals. This result is different from that observed in studies in sheep (FLAIBAN, 2010) and horses (PINTO et al., 2018), which showed elevated $\mathrm{K}^{+}$excretion, and in calves (JUNQUEIRA et al., 2015), which did not show any variation.

During the period of study, goats remained alert and had appetite. No apparent clinical side effects were observed during or after infusions of the solutions. The values of body temperature, heart rate, respiratory rate, and frequency of ruminal movements did not change during or after the infusions $(P>0.05)$ or due to the type of solution infused $(P>0.05)$.

The alkalizing effects of L84 solution have previously been demonstrated in studies conducted in healthy sheep (FLAIBAN, 2010) and calves (JUNQUEIRA et al., 2015). In these studies, L84 solution was also administered in a volume corresponding to $10 \%$ of body weight, but the infusion rate was lower ( 20 and $25 \mathrm{~mL} / \mathrm{kg} / \mathrm{h})$. Another distinction from the previous studies is that, unlike sheep and calves that were followed for only 2 and $2.5 \mathrm{~h}$ after the end of the infusion, the goats were followed for a longer period of time, which allowed us to verify the time in which the iatrogenic imbalance was reversed. Another study, using the L84 solution 
in healthy horses, with different infusion rates (16.66 or $8.33 \mathrm{~mL} / \mathrm{kg} / \mathrm{h}$ ), proved the alkalizing capacity of the solution in this species; however, it was revealed that its magnitude is dependent on the infusion rate (PINTO et al., 2018).

According to the simplified strong ion model (CONSTABLE, 1999; MUIR, 2017), plasma electrolytes influence acid-base balance and blood $\mathrm{pH}$, and plasma $\mathrm{SID}_{3}$ is the representative variable for this event. An increase in the alkalizing capacity of L84 solution could be achieved by tripling the concentration of lactate and decreasing the concentration of $\mathrm{Cl}^{-}$. Thus, $\mathrm{L} 84$ administration resulted in a reduction in chloremia, which increased $\mathrm{SID}_{3}$ and consequently generated iatrogenic metabolic alkalosis. The increase in $\mathrm{SID}_{3}$ at the end of L84 infusion was also demonstrated in healthy sheep, calves, and horses (FLAIBAN, 2010; JUNQUEIRA et al., 2015; PINTO et al., 2018). The effective $\mathrm{SID}_{3}$ of the L84 solution is equivalent to its lactate concentration $(84 \mathrm{mEq} / \mathrm{L})$. With the metabolism of lactate, this anion disappears from the plasma, and the impact of the reduced $\mathrm{Cl}^{-}$concentration assumes the greatest importance because $\mathrm{Cl}^{-}$becomes the only anion infused to exert influence on chloremia and plasma $\mathrm{SID}_{3}$. Therateatwhich iatrogenic hyperlactatemia was reversed reinforced previous observations in sheep and healthy calves that received L84 solution (FLAIBAN, 2010; JUNQUEIRA et al., 2015) and proved that, in healthy goats too, the metabolization of infused lactate is rapid. Therefore, reduction of chloremia, elevation of plasma $\mathrm{SID}_{3}$, and alkalizing effect are already established rapidly during L84 infusion.

The effective SID, total volume and rate of solution administration, and the metabolism of the anions present in the solution are the main determinants of the solution's effect on blood pH (MUIR, 2017). The L84 solution was effective in correcting metabolic acidosis in sheep with ARLA (FLAIBAN, 2010), in calves with diarrhea (JUNQUEIRA, 2012) and in horses with hyperchloremic acidosis (ROMÃO et al., 2017), without causing any side effects. Therefore, this study indicated that the L84 electrolyte solution can be used in the treatment of metabolic acidosis, as long as the organism's ability to metabolize infused lactate is not compromised.

\section{CONCLUSION}

The electrolytic solution containing 84 $\mathrm{mEq} / \mathrm{L}$ of lactate produced iatrogenic alkalization when infused into healthy goats, without causing side effects. Future studies should be conducted to clarify the safety and efficacy of the solution in sick goats.

\section{ACKNOWLEDGEMENTS}

The authors would like to thank Conselho Nacional de Desenvolvimento Científico e Tecnológico (CNPq), and Coordenação de Aperfeiçoamento de Pessoal de Nível Superior (CAPES) for the support in this study.LISBÔA, J.A.N is recipient of the CNPq fellowship.

\section{BIOETHICS AND COMMITTEE APPROVAL}

BIOSSECURITY

The project was approved by the Committee on Ethics in the Use of Animals of the Universidade Estadual de Londrina, under the protocol CEUA / UEL 132/2012.

\section{DECLARATION OF CONFLICT OF INTEREST}

The authors declare no conflict of interest. The founding sponsors had no role in the design of the study; in the collection, analyses, or interpretation of data; in the writing of the manuscript, and in the decision to publish the results.

\section{AUTHORS' CONTRIBUTIONS}

PEREIRA, P.F.V. performed the experiment, provided clinical data, carried out laboratory analysis and wrote the manuscript. ROMÃ̃, F.T.N.M.A, CURTI, J.M and CAMILO, S.L.O. performed the experiment and carried out laboratory analysis. FLAIBAN, K.K.M.C. carried out laboratory analysis and revised the manuscript. LISBÔA, J.A.N designed and supervised the experiment, performed statistical analyses of experimental data and revised the manuscript.

\section{REFERENCES}

ARONSON, P.S, GIEBISH,G. Effects of $\mathrm{pH}$ on potassium: New explanations for old observations. Journal of the American Society of Nephrology, v.22, p.1981-1989, 2011. Available from: <https:// jasn.asnjournals.org/content/22/11/1981>. Accessed: Aug. 10, 2020. doi: 10.1681/ASN.2011040414.

CARLSON, G.P.; BRUSS, M.L. Fluid, electrolyte, and acid base balance. In: KANEKO, J.J.; HARVEY, J.W.; BRUSS, M.L. Clinical Biochemistry of Domestic Animals, $6^{\mathrm{a}}$ ed. Elsevier, London: UK, 2008. p.529-560.

CONSTABLE, P.D. A simplified strong ion model for acid-base equilibrium: application to horse plasma. Journal of Applied Physiology, v.83, p.297-311, 1997. Available form: <https:// pubmed.ncbi.nlm.nih.gov/9216976/> Accessed: May, 01, 2012. doi: 10.1152/jappl.1997.83.1.297.

CONSTABLE, P.D. Acid-base assessment: When and How to apply the Henderson-Hasselbach equation and Strong Ion Difference Theory. Veterinary Clinics of North America: Food Animal Practice, v.30, p.295-316, 2014. Available from: <https://www. vetfood.theclinics.com/article/S0749-0720(14)00024-3/abstract>. Accessed: Aug. 15, 2014. doi: 10.1016/j.cvfa.2014.03.001.

CONSTABLE,P.D.Calculation of variables describing plasma nonvolatile weak acids for use in the strong ion approach to acid-base balance in cattle. American Journal of Veterinary Research, v.63, p.482-490, 2002. Available from: <https://www.ncbi.nlm.nih.gov/pubmed/11939307>. Accessed: May, 01, 2012. doi: 10.2460/ajvr.2002.63.482. 
CONSTABLE, P.D. Clinical assessment of acid-base status strong ion difference theory. Veterinary Clinics of North America: Food Animal Practice, v.15, p.447-471, 1999. Available from: $<$ https://www. vetfood.theclinics.com/article/S0749-0720(15)30158-4/fulltext>. Accessed: May, 01, 2012. doi: 10.1016/S0749-0720(15)30158-4.

CONSTABLE, P.D. Fluid and electrolyte therapy in ruminants. Veterinary Clinics of North America: Food Animal Practice, v.19, p.557-597, 2003. Available from: $<$ https://www.vetfood.theclinics. com/article/S0749-0720(03)00054-9/abstract>. Accessed: May, 01, 2012 doi: 10.1016/S0749-0720(03)00054-9.

CONSTABLE, P.D.; HINCHCLIFF, K.W; DONE, S; GRUENBERG, W. Veterinary Medicine. A textbook of the diseases of cattle, horses, sheep, pigs, and goats. 11 ed.Saunders Ltd, Filadelfia, USA. 2016. 2278p.

COSENZA, M., et al.Efeito da solução de Ringer com lactato sobre os equilíbrios hidroeletrolítico e acidobase de equinos, ovelhas e bezerros sadios. Arquivo Brasileiro de Medicina Veterinária e Zootecnia, v.43, p.2247-2253, 2013. Available from: $<$ https:// www.scielo.br/pdf/cr/v43n12/a33413cr2012-1182.pdf >.Accessed: Aug. 15, 2014. doi: 10.1590/S0103-84782013005000128.

COSENZA, M., et al. Efeito alcalinizante da solução Ringer com lactate em ovelhas sadias e acidóticas. Arquivo Brasileiro de Medicina Veterinária eZootecnia, v.67, p.855-863, 2015. Availablefrom: $<$ https:// www.scielo.br/pdf/abmvz/v67n3/0102-0935-abmvz-67-03-00855. pdf>. Accessed: Jan. 05, 2016. doi: 10.1590/1678-4162-6501.

FLAIBAN, K.K.M.C. Efeito alcalinizante de soluções eletrolíticas contendo lactato de sódio em ovelhas sadias e com acidose metabólica induzida. 2010. 134fl. Tese (Doutorado em Ciência Animal) - Curso de pós graduação em Ciência Animal, Universidade Estadual de Londrina.

GARRY, F., CHEW, D.J., RINGS, D.M. Renal excretion of creatinine, electrolytes, protein and enzymes in healthy sheep. American Journal of Veterinary Research, v.51, p.414 419, 1990. Available from: <https://pubmed.ncbi.nlm.nih. gov/1969253/>. Accessed: May, 01, 2012.

JONES, M, NAVARRE, C. Fluid therapy in small ruminants and camelids.Veterinary Clinics of North America: Food Animal Practice, v.30, p.441-453, 2014. Available from: <https://www. vetfood.theclinics.com/article/S0749-0720(14)00033-4/fulltext>. Accessed: Aug. 15, 2014. doi: 10.1016/j.cvfa.2014.04.006.

JUNQUEIRA, J.R.C. Efeito alcalinizante de soluções eletrolíticas com concentração elevada de lactato de sódio administradas em bezerros sadios e diarréicos com acidose metabólica. 2012. 114fl. Tese (Doutorado em Ciência Animal) - Curso de pós graduação em Ciência Animal, Universidade Estadual de Londrina.

JUNQUEIRA, J.R.C., et al.Efeito alcalinizante de soluções eletrolíticas intravenosas com concentrações elevadas de lactato de sódio infundidas em bezerros sadios. Arquivo Brasileiro de Medicina Veterinária e Zootecnia, v.67, p.15-24, 2015.Available from: <https:// www.scielo.br/pdf/abmvz/v67n1/0102-0935-abmvz-67-01-00015. pdf $>$. Accessed: Jan. 03, 2016. doi: 10.1590/1678-6754.

LEAL, M.L.R., et al.,Estudo da capacidade alcalinizante de tampões metabolizáveis em bovinos sadios. Arquivo Brasileiro de Medicina Veterinária e Zootecnia, v.59, p.965970, 2007. Availablefrom: <https://www.scielo.br/pdf/abmvz/ v59n4/23.pdf $>$ Accessed: May, 01, 2012. doi: 10.1590/S010209352007000400023.
LUNN, D.P.; MCGUIRK, S.M. Renal regulation of electrolyte and acid-base balance in ruminants. Veterinary Clinics of North America: Food Animal Practice, v.6, p.1-28, 1990. Available from: $<$ https://pubmed.ncbi.nlm.nih.gov/2178735/>. Accessed: May, 01, 2012. doi: 10.1016/s0749-0720(15)30891-4

MUIR, W. Effect of intravenously administered crystalloid solutions on acid base balance in domestic animals. Journal of Veterinary Internal Medicine, v.31, p.1371-1381, 2017. Available from: <https:/onlinelibrary.wiley.com/doi/full/10.1111/ jvim. 14803>. Accessed: Jul. 31, 2020. doi: 10.111/jvim. 14803.

NAKAGAWA, M.et al.,. Comparison of the alkalinizing effects of bicarbonate precursors in claves with experimentally induced metabolic acidosis. Journal Veterinary Medical Science, v.71, p.807-809, 2009. Available from: <https://pubmed.ncbi.nlm. nih.gov/19578293/> Accessed: May, 01, 2012. doi: 10.1292/ jvms.71.807.

NAYLOR, J.M, FORSYTH, G.W. The alkalinizing effect of metabolizable bases in healthy calf. Canadian journal of Veterinary Research, v.50, p.509-516, 1986. Available from: $<$ https://www.ncbi.nlm.nih.gov/pmc/articles/PMC1255256/>. Accessed: May, 01, 2012.

PINTO, F.C, et al.,A velocidade de infusão da solução poli-iônica intravenosa contend $84 \mathrm{mEq} / \mathrm{L}$ de lactate determina a intensidade do efeito alcalinizante em equinos. Arquivo Brasileiro de Medicina Veterinária Zootecnia, v.70, p.37-44, 2018. Available from: $\quad<$ https://www.scielo.br/pdf/abmvz/v70n1/0102-0935abmvz-70-01-00037.pdf $>$. Accessed: Oct. 15, 2019. doi: $10.1590 / 1678-4162-9564$.

PUGH, D.G.; BAIRD, A.N.; EDMONDSON, M.A.; PASSLER, T. Sheep, Goat and Cervid Medicine. 3 ed. Elsevier Inc, Filadélfia, USA. 2020. 576p.

ROMÃO, F.T.N.M.A., PEREIRA, P.F.V., FLAIBAN, K.K.M.C., DEARO, A.C.O., FERNANDES, T.M., LISBÔA, J.A.N. Intravenous administration of a polyionic solution containing $84 \mathrm{mEq} / \mathrm{L}$ of lactate resolves experimentally induced hyperchloremic acidosis in horses. Equine Veterinary Journal, v.49, p.87-93, 2017. Available from: <https://beva onlinelibrary.wiley.com/doi/abs/10.1111/evj.12525>. Accessed: May, 05, 2017. doi: 10.111/evj12525.

SMITH, G.W., BERCHTOLD, J. Fluid therapy in calves. Veterinary Clinics of North America: Food Animal Practice, v.30, p.409-428, 2014. Available from: <https://pubmed.ncbi.nlm. nih.gov/24980729/>. Accessed: Aug. 15, 2014. doi: 10.1016/j. cvfa.2014.04.002

SNYDER, E., CREDILLE, B. Diagnosis and treatment of clinical rumen acidosis. Veterinary Clinics of North America: Food Animal Practice, v.33, p.451-461, 2017. Available from: $\quad<$ https://www.vetfood.theclinics.com/article/S07490720(17)30056-7/fulltext>. Accessed: Jul. 20, 2020. doi: 10.1016/j.cvfa.201.06.003.

TREFZ, FM., LORCH A., ZITZL, J., KUTSCHKE, A., KNUBBEN-SCWEIZER, G., LORENZ, I. Effects of alkalinization and rehydration on plasma potassium concentrations in neonatal calves with diarrhea. Journal of Veterinary Medicine, v.29, p.606704, 2015. Available from: <https://onlinelibrary.wiley.com/ doi/10.1111/jvim.12537>. Accessed: Aug. 10, 2020. doi: 10.111/ jvim. 12537. 